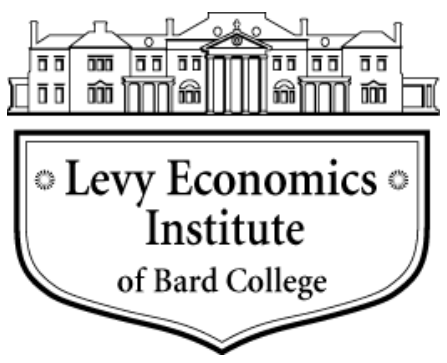

Working Paper No. 951

\title{
A Simple Model of the Long-Term Interest Rate
}

\author{
by
}

\author{
Tanweer Akram* \\ General Motors
}

\section{April 2020}

The Levy Economics Institute Working Paper Collection presents research in progress by Levy Institute scholars and conference participants. The purpose of the series is to disseminate ideas to and elicit comments from academics and professionals.

Levy Economics Institute of Bard College, founded in 1986, is a nonprofit, nonpartisan, independently funded research organization devoted to public service. Through scholarship and economic research it generates viable, effective public policy responses to important economic problems that profoundly affect the quality of life in the United States and abroad.

\author{
Levy Economics Institute \\ P.O. Box 5000 \\ Annandale-on-Hudson, NY 12504-5000 \\ http://www.levyinstitute.org
}

Copyright (C) Levy Economics Institute 2020 All rights reserved

\section{ISSN 1547-366X}

\footnotetext{
* The author thanks the participants in various seminars for their invaluable comments and suggestions. He also thanks Ms. Elizabeth Dunn and Ms. Mary Rafferty for their editorial assistance. Disclaimer: The author's institutional affiliation is provided solely for identification purposes. Views expressed are solely those of the author and are not necessarily those of General Motors. The standard disclaimers hold.
} 


\begin{abstract}
This paper presents a simple model of the long-term interest rate. The model represents John Maynard Keynes's conjecture that the central bank's actions influence the long-term interest rate primarily through the short-term interest rate, while allowing for other important factors. It relies on the geometric Brownian motion to formally model Keynes's conjecture. Geometric Brownian motion has been widely used in modeling interest rate dynamics in quantitative finance. However, it has not been used to represent Keynes's conjecture. Empirical studies in support of the Keynesian perspective and the stylized facts on the dynamics of the long-term interest rate on government bonds suggest that interest rate models based on Keynes's conjecture can be advantageous.
\end{abstract}

KEYWORDS: Long-Term Interest Rate; Bond Yields; Monetary Policy; Short-Term Interest Rate; John Maynard Keynes

JEL CLASSIFICATION: E12; E43; E50; E58; E60; G10; G12; G41 


\section{INTRODUCTION}

John Maynard Keynes conjectured that a country's central bank has a decisive influence on the long-term interest rate on risk-free government bonds, mainly through its policy rate and monetary policy actions. He argued that the central bank's decisions on the policy rate set the short-term interest rate, which has a crucial effect on the long-term interest rate of risk-free government bonds. Keynes's views on the central bank's influence on government bond yields and the shape of government bond yield curves were articulated in his Treatise on Money (1930a, 1930b) and General Theory ([1936] 2007).

Keynes's conjecture on interest rates is based on both theory and stylized empirical facts (Kregel 2011). The theoretical basis rest on his analysis of the central bank's policy rate, open market operations, and balance sheet policies (Keynes 1930a, 185-220; 1930b, 362-364, 369-373), as well as his theory of interest rates (Keynes 1930b, 352-361; [1936] 2007, 165-185, 222-244) and liquidity preference (Keynes [1936] 2007, 194-209). The empirical basis for the conjecture comes from Riefler's (1930) statistical study of money markets and bond markets in the United States in the 1920s and Keynes's (1930b, 355-356) observations of the same markets in the United Kingdom during that period.

In recent years, the Keynesian approach to modeling long-term government bond yields has been revived and revitalized. The Keynesian approach has contested the conventional position that relies on the loanable funds theory of interest rates, which holds that increased fiscal deficit and higher government debt ratios exert upward pressures on government bond yields, and that higher deficit and debt ratios increase the likelihood of sovereign debt defaults. Reinhart and Rogoff (2009) embody and epitomize the conventional position; Simoski (2019, 8-21) provides a critical review of both the conventional and the Keynesian approaches.

The Keynesian approach, however, has not yet deployed the substantial theoretical work on interest rate modeling that exists in the quantitative finance literature. In the same vein, the existing quantitative finance literature has yet to appropriate Keynes's valuable insights on the dynamics of the long-term interest rate based on his deep and original analysis of financial 
markets, investors' long-term expectations, and institutional features of advanced capitalism, even though there is a growing body of literature that provides empirical support for the Keynesian approach.

This paper addresses this crucial gap in interest rate modeling. It develops a Keynesian model of interest rate dynamics based on geometric Brownian motion using stochastic differential equations. This paper also relates the long-term interest rate, the short-term interest rate, the central bank's policy rate, other relevant macroeconomic variables, and stochastic shocks in a simple model that provides a useful understanding of interest rate dynamics based on Keynes's insights.

The paper progresses as follows. Section 2 briefly describes Keynes's view on interest rates. Section 3 presents a model based on the geometric Brownian motion in the quantitative finance literature to represent Keynes's conjecture that relates the central bank's decisive influence on the long-term interest rate through its policy rate, the short-term interest rate, and other relevant variables. Section 4 draws attention to some stylized facts that show the evolution of interest rates in advanced countries are consistent with the simple Keynesian model. Section 5 discusses the policy relevance of Keynes's conjecture in contemporary debates in macroeconomic theory and policy issues. Section 6 provides a conclusion.

\section{KEYNES'S VIEWS ON INTEREST RATES}

Keynes was acutely aware of the institutional features of capitalist production processes and financial systems, as pointed out in Kregel (1980). Thus, he understood the central bank's ability to influence the long-term interest rate and the shape of the yield curve in actual capitalist economies with money, financial assets, and financial institutions. In actual capitalist economies, investors who are engaged in business investment, financing, and financial speculation play a critical role. He stated: 
a. "The efficacy of Bank-rate for the management of a managed money was a great discovery and a most novel one ... its precise modus operandi and the varying results to be expected from its application in varying conditions were not clearly understood — and have not been clearly understood ... down to this day." (Keynes 1930a, 17)

b. "The main, direct influence of the Banking System is over the short-term rate of interest. But when it is a question of controlling the rate of investment, not in working capital but in fixed capital, it is the long-term rate of interest which chiefly matters." (Keynes 1930b, 352)

c. "[E]xperience shows that ... the influence of the short-term interest rate on the long-term rate is much greater than anyone ... would have expected. ... [T] here are some sound reasons based on the technical character of the market, why it is not unnatural that this should be so." (Keynes 1930b, 353)

d. "[S]hort-term rates influence long-term rates more than the reader might expect ... it is not difficult to find sufficient explanation for this observed fact." (Keynes 1930b, 362)

e. "[T]here is no reason to doubt the ability of a Central Bank to make its short-term rate of interest effective in the market." (Keynes 1930b, 363)

f. "It should not be beyond the power of a Central Bank (international complications apart) to bring down the long-term market rate of interest to any figure at which it is itself prepared to buy long-term securities." (Keynes 1930b, 371)

g. "[T]he long-term market rate of interest will depend, not only on the current policy of the monetary authority, but also on the market expectations concerning its future policy. The short-term interest rate is easily controlled by the monetary authority. ... But the long-term rate may be more recalcitrant." (Keynes [1936] 2007, 202-203)

h. "If the monetary authority were prepared to deal both ways on specified terms in debts of all maturities, and even more so if it were prepared to deal in debts of varying degrees of risk, the relationship between the complex rate of interest and the quantities of money would be direct." (Keynes [1936] 2007, 205)

i. "[A] complex offer by the central bank to buy and sell at stated prices gilt-edged bonds of all maturities, in place of the single bank rate for short-term bills, is the most important practical improvement which can be made in the technique of monetary management." (Keynes [1936] 2007, 206)

j. "If the monetary authority deals only in short-term debts, we have to consider what influence the price, actual and prospective, of short-term debts exercise on debts of longer maturity." (Keynes [1936] 2007, 206)

Keynes argued that the interest rate is a return for the willingness to give up holding cash or bank money rather than a return to saving or waiting. He repudiated the loanable funds theory. Liquidity preference is the basis for interest rates. It arises because of: (1) "uncertainty as to the future of the rate of interest"; and (2) difference among investors regarding their assessments of the uncertain and unknown future. He classifies several motives for holding liquid assets: (1) income motive; (2) business motive; (3) precautionary motive; (4) speculative motive; and (5) finance motive.

Keynes points out that since the central bank controls the policy rate, it has direct influence on the short-term interest rate. However, he also argues that the short-term interest rate has a decisive and noticeable effect on the long-term interest rate, much more than appears warranted. He wrote: "For whilst it is reasonable that long-term rates should have a definite relation to the prospective short-term rates, quarter-by-quarter, over the years to come, the contribution of 
current three-monthly period to this aggregate expectation should be insignificant in amount — so one might suppose” (Keynes 1930b, 352).

However, the influence of the current short-term interest rate on the long-term interest rate is much larger than a simple model of the long-term interest rate. In that model, it is a function of the current short-term interest rate and the expected path of the future short-term interest rate or forward rates. The current short-term interest rate is only one factor in that model, and its role would be fairly limited compared to the future short-term interest rates or forward rates.

Keynes (1930b, 353-362; [1936] 2007, 147-164) explains this apparent anomaly in terms of various technical characteristics of financial markets and institutional attributes of banks, money managers and financial institutions, investors' long-term expectations, psychological conventions and sociological considerations, and rational herding in financial markets. Above all, fundamental uncertainty prevents investors from having well-defined mathematical expectations about for the future and investment opportunities.

The influence of the short-term interest rate on long-term interest rates has been welldocumented in various studies on government bond yields. Table 1 provides references documenting this relationship.

Table 1: Recent Studies That Document the Connection Between the Short-Term Interest Rate and the Long-Term Interest Rate

\begin{tabular}{|l|l|}
\hline Country/Region & Studies \\
\hline United States & $\begin{array}{l}\text { Akram and Li (2016, 2017, 2019b); Akram and Das (2019b); } \\
\text { Levrero and Deleidi (2019) }\end{array}$ \\
\hline Eurozone & Akram and Das (2017) \\
\hline Japan & Akram and Das (2014), Akram and Li (2018, 2019a) \\
\hline Canada & Akram and Das (2020) \\
\hline Australia & Akram and Das (Forthcoming) \\
\hline Latin America & Simoski (2019), Akram and Uddin (2020) \\
\hline India & $\begin{array}{l}\text { Vinod, Chakraborty, and Karun (2014); Akram and Das (2015, } \\
\text { 2019a); Patra, Pattanaik, and Behera (2016) }\end{array}$ \\
\hline Others & Malliaropulos and Migiakis (2018) \\
\hline
\end{tabular}




\section{A KEYNESIAN MODEL OF THE LONG-TERM INTEREST RATE DYNAMICS}

Several of the well-known interest rate models in the quantitative finance literature are analytically simple and elegant. The best known of these interest models are by Vasicek (1977), Dothan (1978), Cox, Ingersoll, and Ross (1985), Heston (1993), Ho and Lee (1986), Hull and White (1990a, 1990b), Black, Derman, and Toy (1990), Heath, Jarrow, and Morton (1992), and Brace, Gatarek, and Musela $(1997)$. Rebonato $(1996,2004)$ provides a detailed summary and overview of most of them.

None of these models, however, incorporate Keynes's fundamental insights and observations about the relationship between the central bank's monetary policy actions and the long-term interest rate. In recent years, research on the long-term interest rate, inspired by the Keynesian approach, has been renewed. These empirical studies - including those cited in section 2-are still disconnected from the interest rate models in the quantitative finance literature.

Hence, the model presented here attempts to bridge the gap between Keynes's insightful observations about interest rate dynamics and financial markets, and the interest rate modeling literature in quantitative finance. It does so by emphasizing the connections between the central bank's policy rate, the short-term interest rate, the long-term interest rate, and the overall macroeconomy. The model below is quite similar to that in Heston (1993) but has incorporated some crucial insights drawn from Keynes (1930a, 1930b, [1936] 2007).

\section{Notation}

The long-term interest rate is $r_{L T}$, the short-term interest rate is $r_{S T}$, and the central bank policy rate is $r_{C B}$. Volatility is $V$ and various macroeconomics factors, such as the rate of core inflation, the growth of industrial production, and the ratio of government debt to nominal GDP, are represented as $W_{i}$. The correlation between the Weiner process, $d z$, and the $i$ th macroeconomic factor is $\rho_{i}$. 


\section{Equations}

The interest rate model is represented in the following four equations:

$$
\begin{aligned}
& d r_{L T}=\mu r_{S T} d t+\sqrt{V} r_{S T} d z \\
& d r_{S T}=\alpha\left(r_{C B}-r_{L T}\right) d t+\varepsilon_{t} \\
& d V=\kappa(\theta-V) d t+\sigma \sqrt{V} \sum_{i=1}^{N} d W_{i} \\
& d z d W_{i}=\rho_{i} d t \forall i
\end{aligned}
$$

Equation 1 states that the long-term interest rate follows a geometric Brownian motion that satisfies the above stochastic differential equation. Here, $d z$ is a Weiner process; $\mu$ is the drift, and $V$ is the volatility. Both the drift and the volatility terms are constant.

Equation 2 states that the short-term interest rate, $r_{S T}$, is a mean reverting function of the central bank's policy rate, $r_{C B}$, at a pace of $\alpha$. Here, $\varepsilon_{t}$ is an error term.

Equation 3, the equation for volatility, implies that the volatility is a mean reverting to $\theta$ at a rate set by $\kappa$. Here, $\sigma$ is the standard deviation of the volatility and $W_{i}$ is a random variable that represents the shock from the $i$ th macroeconomic variable.

Equation 4 indicates that $\rho_{i}$ is the correlation between the Weiner process, $d z$, and the $i$ th macroeconomic factor, $d W_{i}$. 


\section{STYLIZED FACTS}

The short-term interest rate very closely tracks the central bank's policy rate. The long-term interest rate generally moves in lockstep with the short-term interest rate. The figures below reveal these stylized facts about the dynamics of interest rates in major advanced countries and regions, including the United States (figure 1), Canada (figure 2), the eurozone (figures 3 and 4), the United Kingdom (figure 5), and Japan (figure 6), along with selected emerging markets, such as China (figure 7), India (figure 8), Brazil (figure 9), and Mexico (figure 10). Even though the short-term interest rate and the central bank's policy rate are very strongly correlated, and the long-term interest rate and the short-term interest rate are strongly correlated, there are some random variations in the underlying trends due to a wide range of incoming macroeconomic information, technical characteristics of financial markets, policy pronouncements and regulatory changes, policy uncertainty, business cycles, and other factors.

Figure 1: The Evolution of Key Interest Rates in the United States, 2000-19

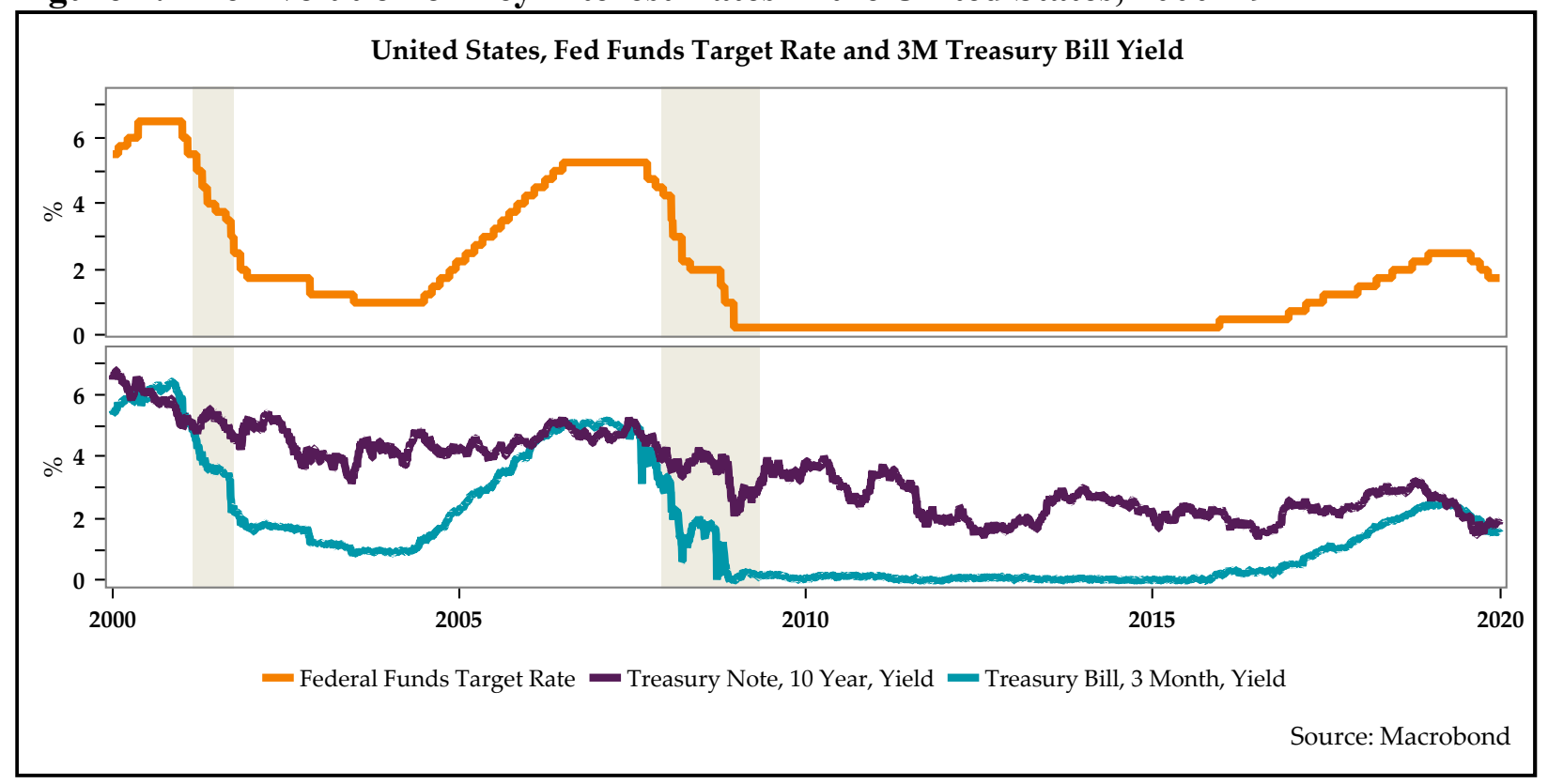


Figure 2: The Evolution of Key Interest Rates in Canada, 2000-19

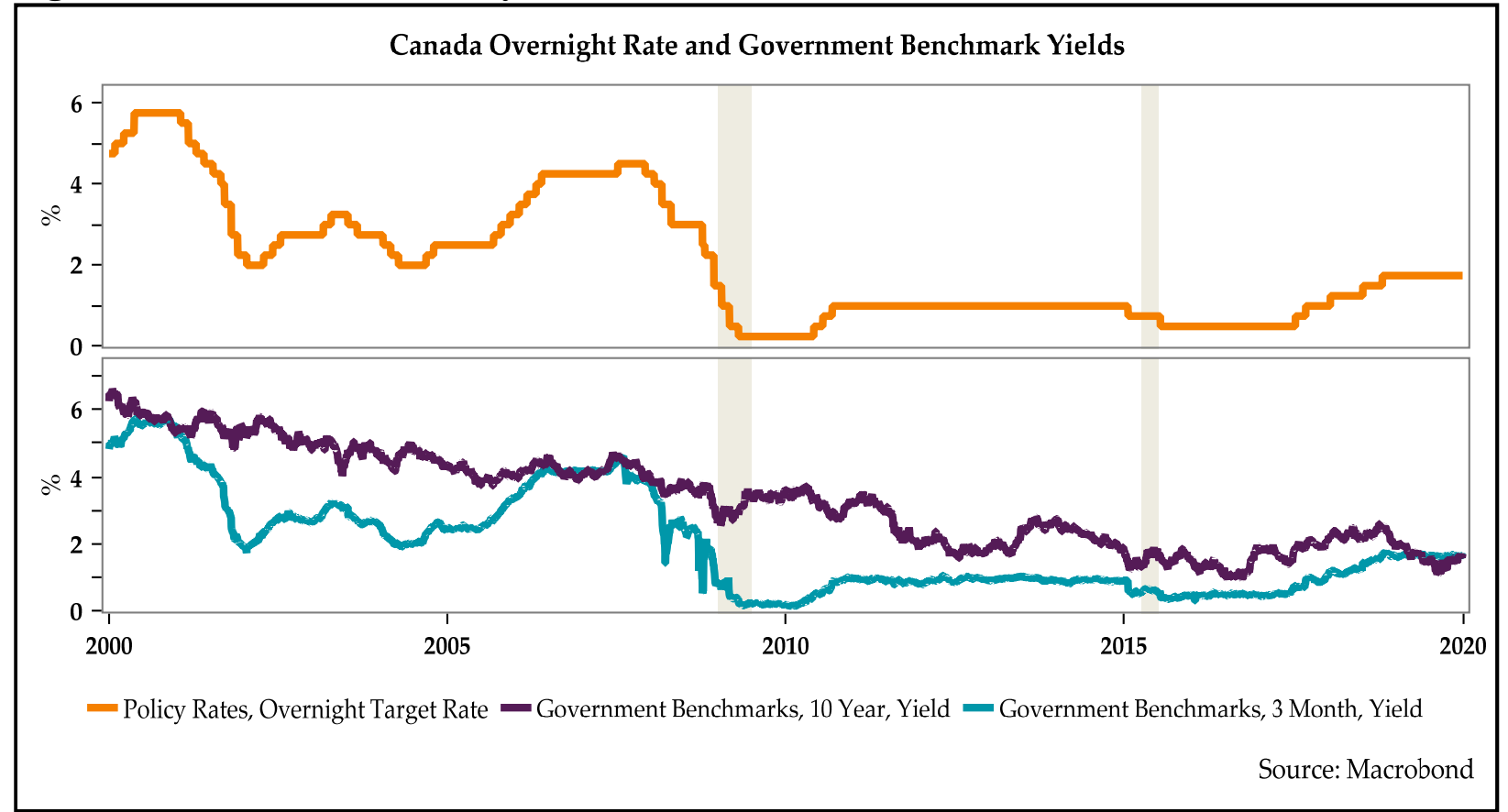

Figure 3: The Evolution of Key Short-Term Interest Rates in the Eurozone, 2000-19

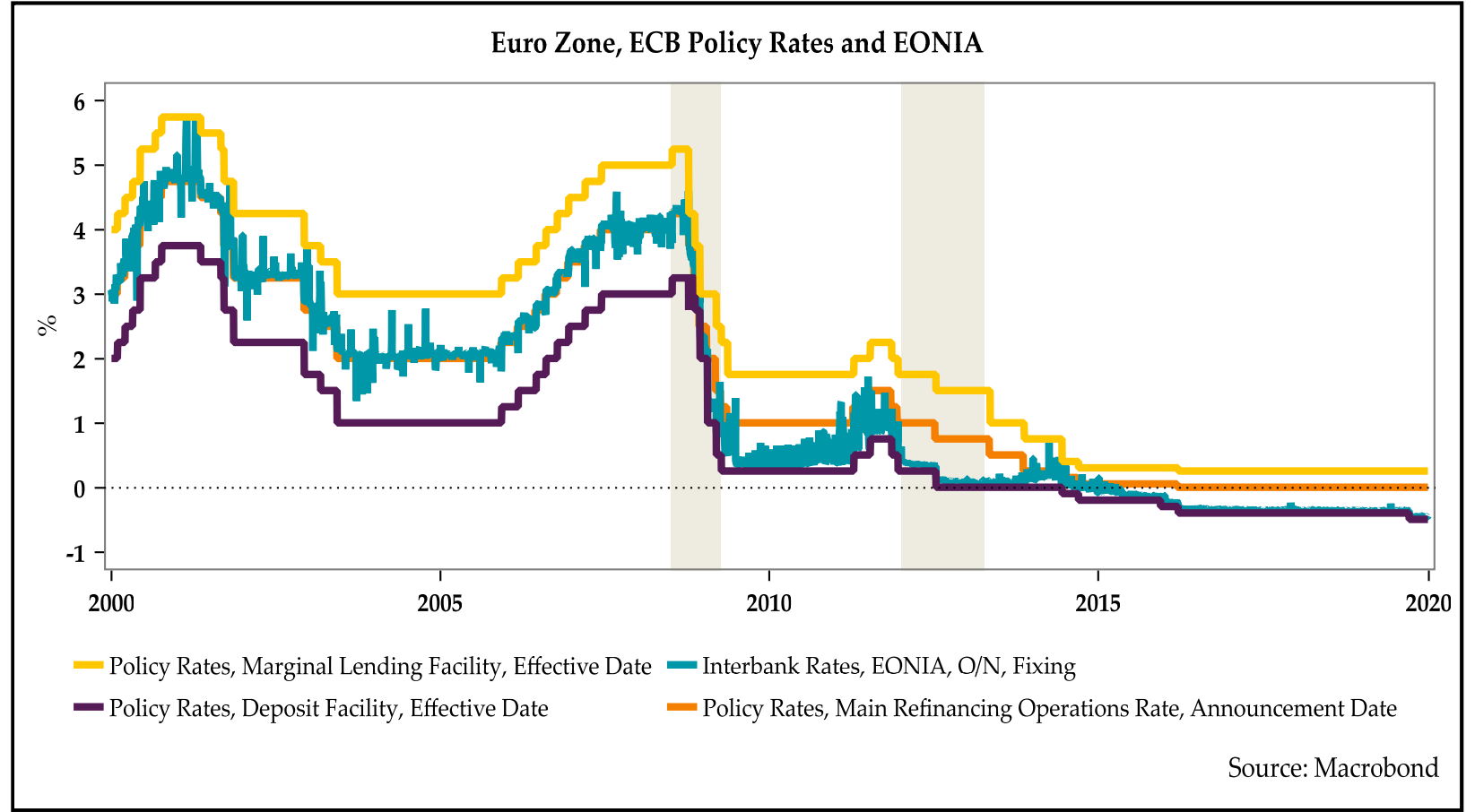


Figure 4: The Evolution of Long-Term Interest Rates in Major Eurozone Economies, 2000-19

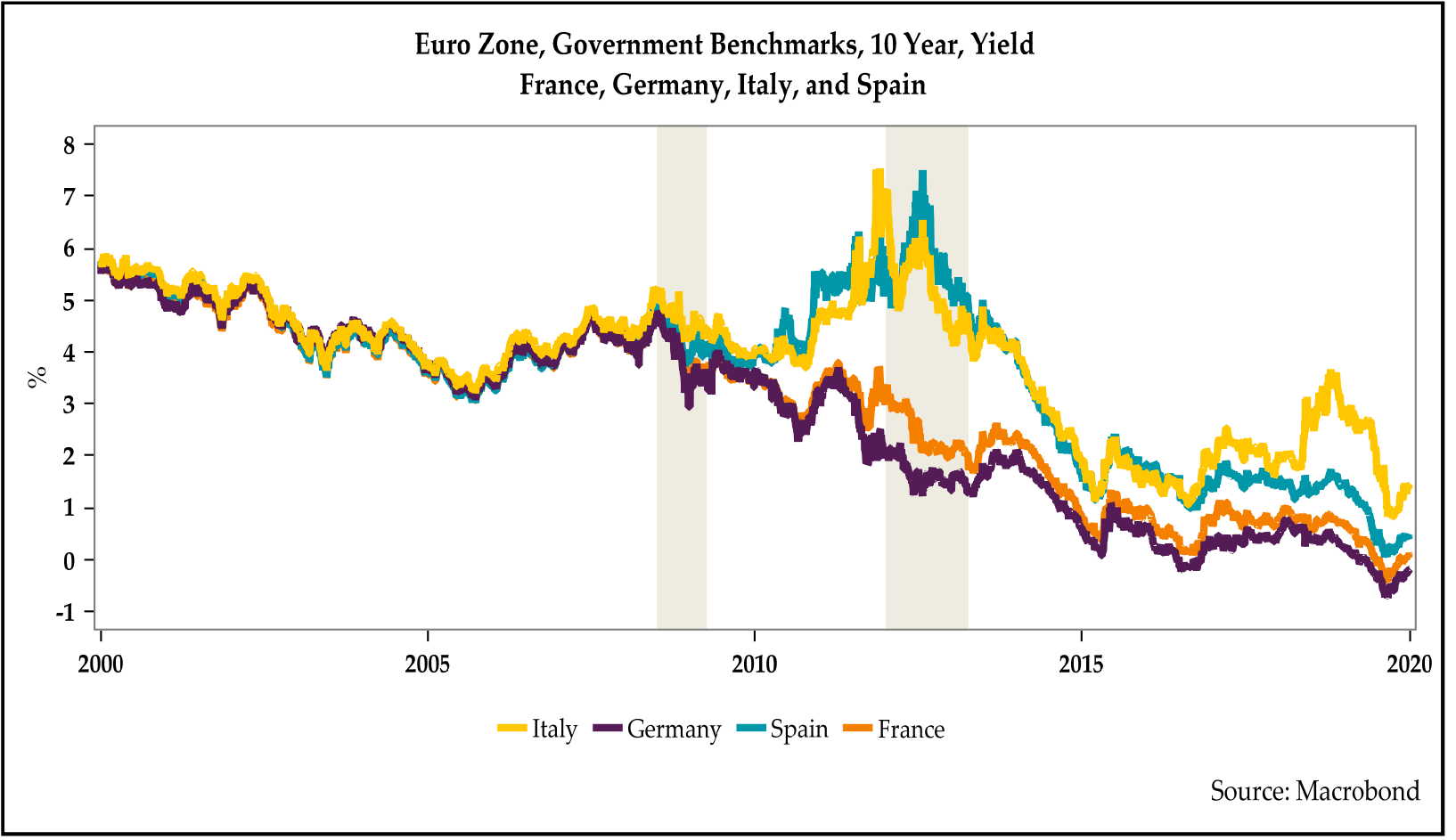

Figure 5: The Evolution of Key Interest Rates in the UK, 2000-19

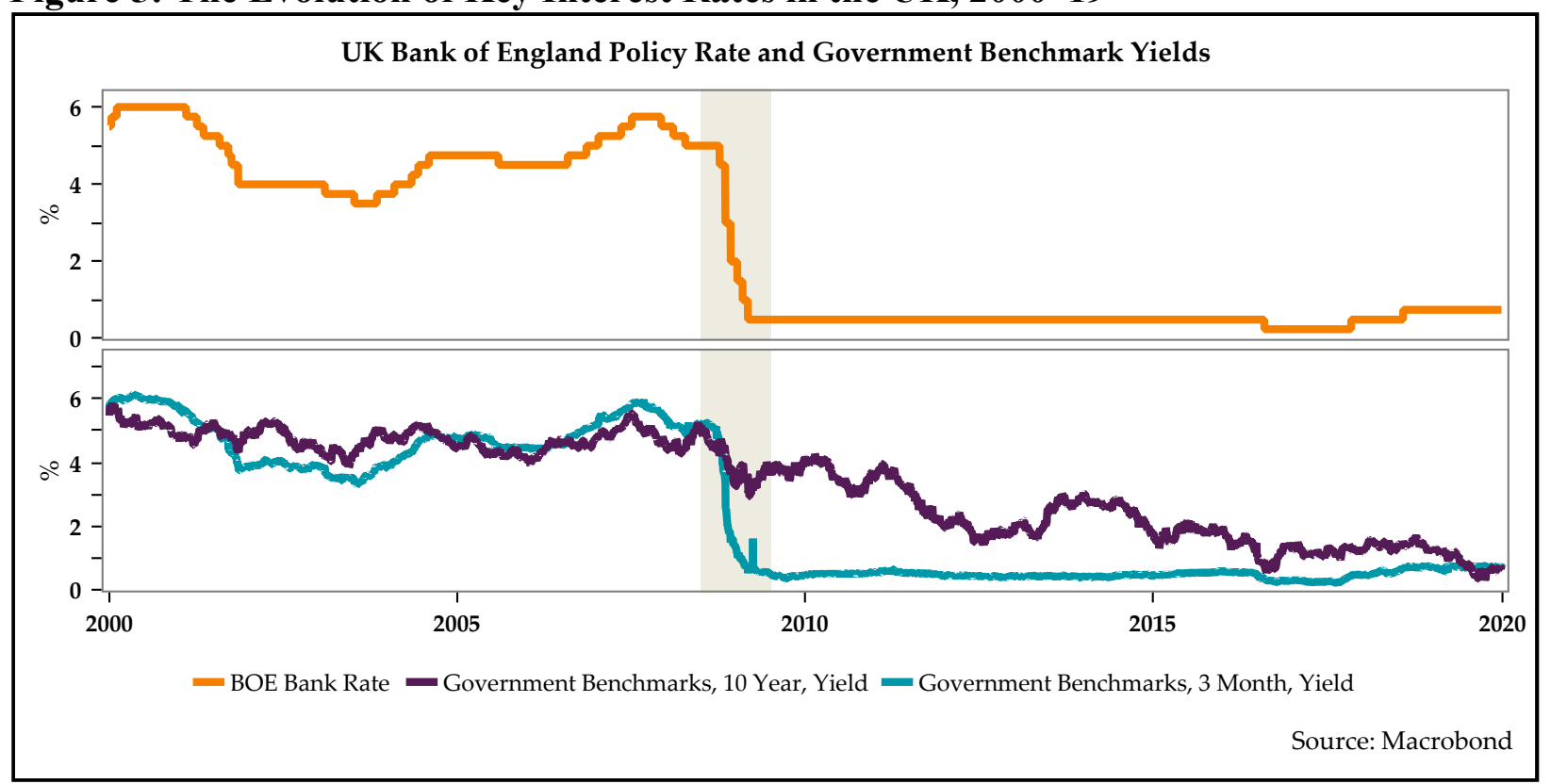


Figure 6: The Evolution of Key Interest Rates in Japan, 2000-19

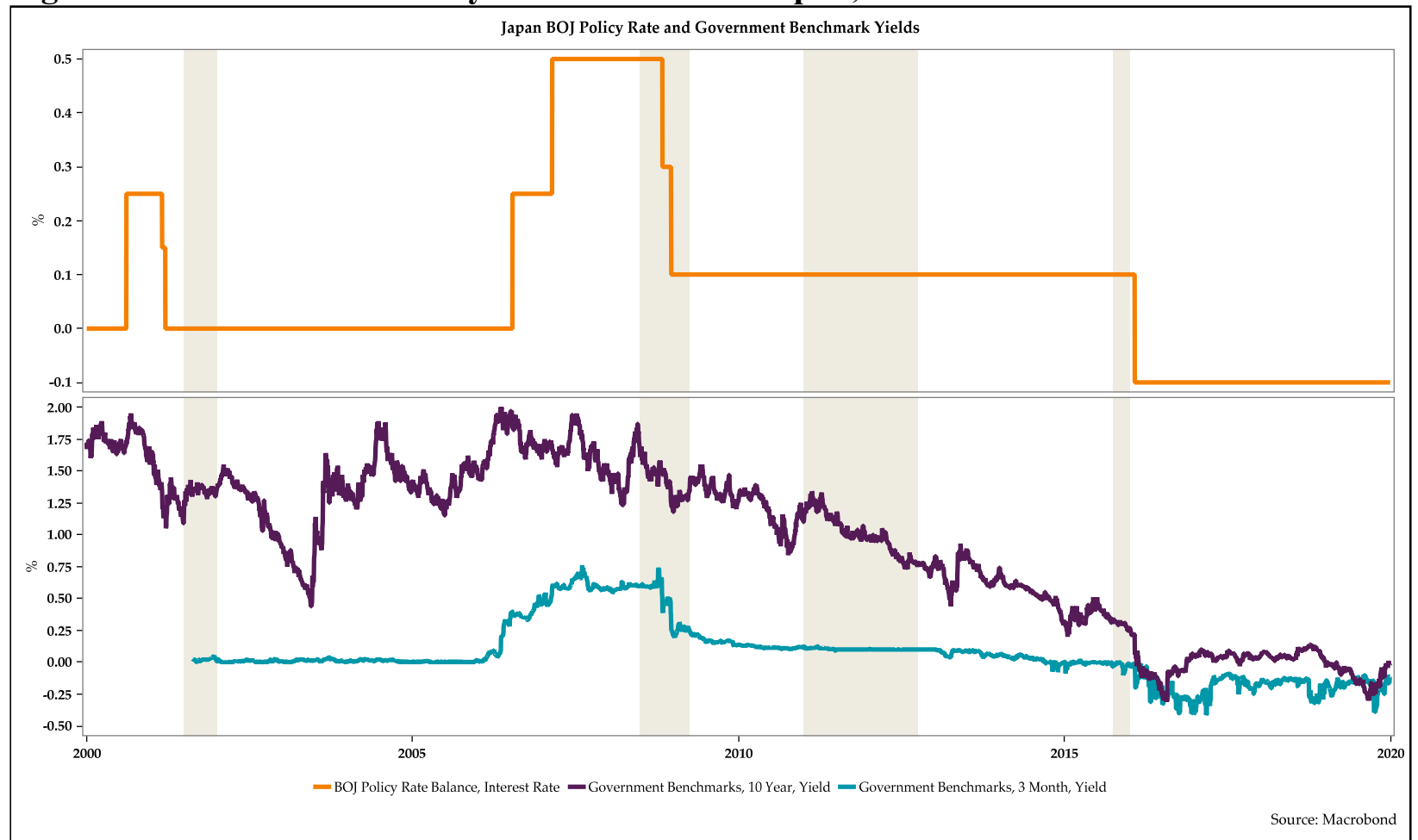

Figure 7: The Evolution of Key Interest Rates in China, 2000-19

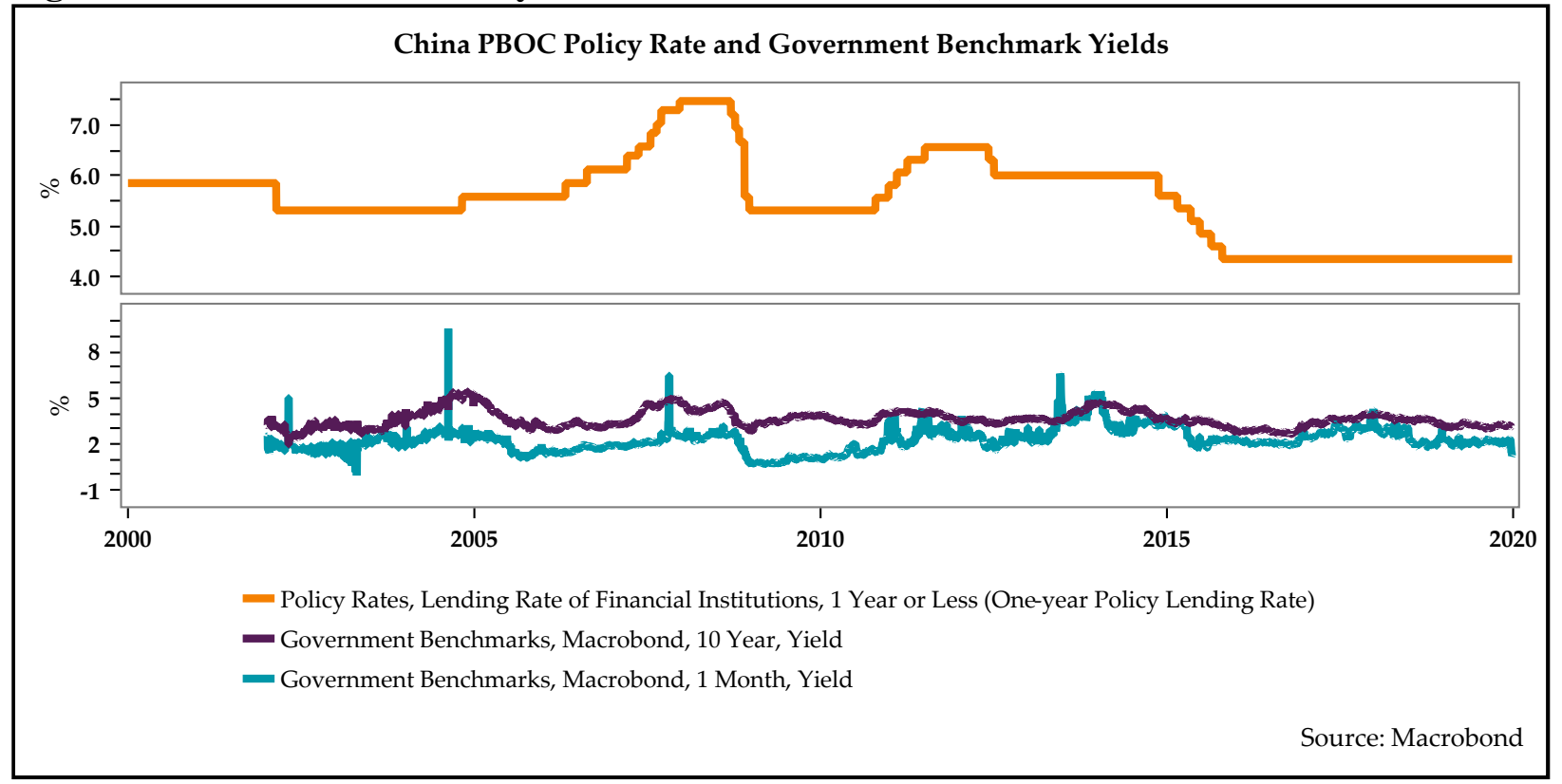


Figure 8: The Evolution of Key Interest Rates in India, 2000-19

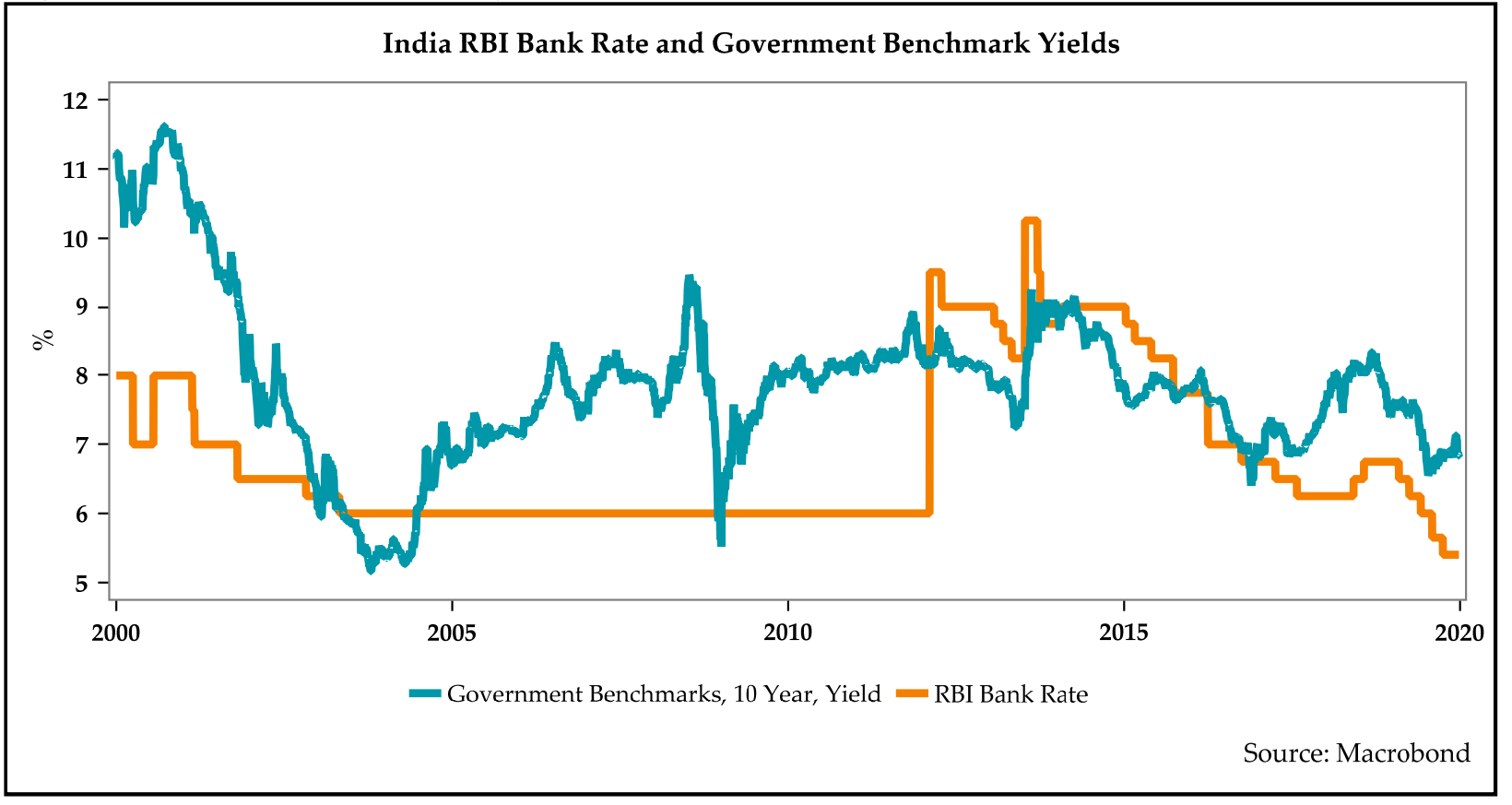

Figure 9: The Evolution of Key Interest Rates in Brazil, 2010-19

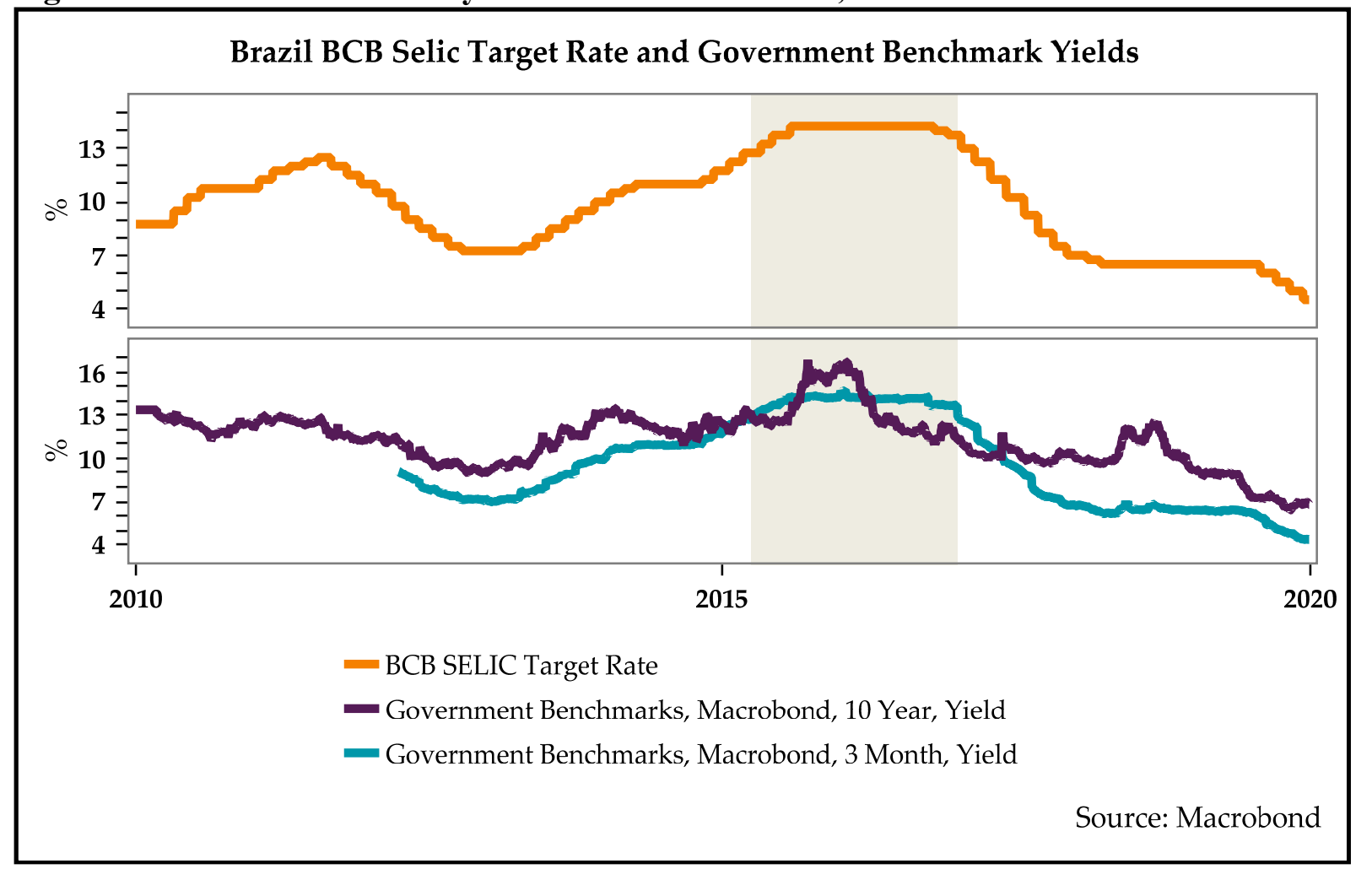


Figure 10: The Evolution of Key Interest Rates in Mexico, 2005-19

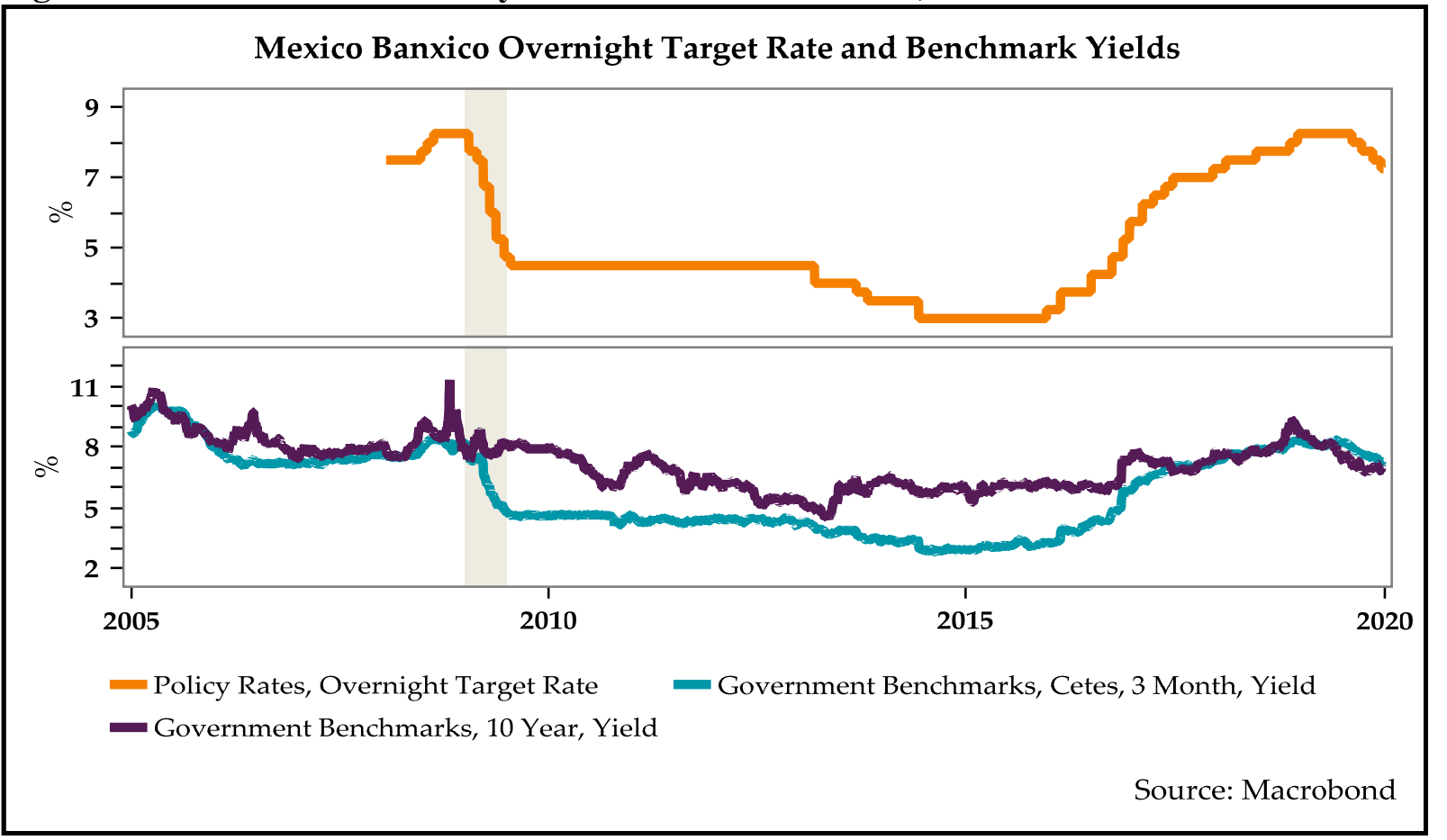

\section{POLICY RELEVANCE}

The simple model for the long-term interest rate developed here is relevant not just for macroeconomic and finance theory but also for monetary and fiscal policy. In this model, a higher (lower) short-term interest rate is associated with a higher (lower) long-term interest rate on government bonds. The central bank affects government bond yields through policy rates, such as the overnight financing rate, the interest rate on reserves, and so forth. The central bank's policy rate decision is affected by its statutory mandates, inflationary pressures, inflation expectations, current economic and financial conditions, and its forecast of the economic outlook and the balance of risks. In the final analysis, the central bank is a key driver of the long-term interest rate and the shape of the yield curve. Under monetary sovereignty, as defined in Wray (2012), the central bank has the operational ability and flexibility to effectively influence the long-term interest rate on government bond yields on government debt in local currency, provided that a regime of floating exchange rate is maintained. 
This model emphasizes the fundamental role of the central bank in influencing the long-term interest rate and the shape of the Treasury yield curve, in contradistinction to the loanable funds theory, which holds that the interest rate is simply the price of loanable funds and depends on the demand and supply of funds. This model of the interest rate can be enhanced and extended to illuminate policy issues and discussions related to government debt management, fiscal sustainability, fiscal policy, and the central bank's ability to control long-term interest rates on government bonds. It also can be used to assess the efficacy of monetary policy and the monetary transmission mechanism.

A policy framework that recognizes the Keynesian approach and models the dynamics of interest rates accordingly can contribute to various debates, such as those related to the following:

(1) The effects of government fiscal variables on government bond yields (Ardagna, Caselli, and Lane 2007; Gruber and Kamin 2012; Horioka, Nomoto, and TeradaHagiwara 2014; Hoshi and Ito 2013; Jaramillo and Weber 2013; Min et al. 2003; Poghosyan 2014; Tkačevs and Vilerts 2019; Turner 2002);

(2) asset prices (Kurihara 2015);

(3) operational issues on central banking and government debt management (Bindseil 2004; Das et al. 2010; Fullwiler 2016, [2008] 2017; Mattos et al. 2019);

(4) fiscal theory of price (Bölükbaş 2018; Sims 2013);

(5) functional finance (Lerner 1943);

(6) fiscal and monetary policy (Sau 2018); and

(7) monetary theory (Goodheart 1998; Wray [1998] 2003, 2012). 


\section{CONCLUSION}

This paper presents a simple model of the long-term interest rate. This model is based on Keynes's conjecture that the central bank's actions influence the long-term interest rate primarily through the short-term interest rate. The central bank's policy rate has a decisive influence on the short-term interest rate, according to Keynes. The short-term interest rate, along with central bank actions and various macroeconomic factors, is a key driver of the long-term interest rate. The model applies geometric Brownian motion, as represented in stochastic differential equations - which are widely used in modeling interest rate dynamics in quantitative finance - to represent Keynes's conjecture. Various empirical studies and the stylized facts on the evolution of the long-term interest rate on government bonds in advanced countries and selected emerging markets support Keynes's conjecture. This suggests that a simple model of the long-term interest rate, based on the Keynesian approach, might be useful not merely for understanding interest rate dynamics but also for addressing a wide range of theoretical questions in macroeconomics and finance, and in contemporary debates on monetary, fiscal, and other economies policies. 


\section{REFERENCES}

Akram, T., and A. Das. 2014. "Understanding the Low Yields of the Long-Term Japanese Sovereign Debt." Journal of Economic Issues 48(2): 331-40.

- 2015. "A Keynesian Explanation of Indian Government Bond Yields." Journal of Post Keynesian Economics 38(4): 565-87.

— 2017. "The Dynamics of Government Bond Yields in the Eurozone." Annals of Financial Economics 12(3): 1750011-18.

— . 2019a. "The Long-Run Determinants of Indian Government Bond Yields." Asian Development Review 36(1): 168-205.

—. 2019b. "An Analysis of the Daily Changes in US Treasury Security Yields." Levy Economics Institute Working Paper No. 934. Annandale-on-Hudson, NY: Levy Economics Institute of Bard College.

—. 2020. "The Empirics of the Canadian Government Securities Yields." Unpublished work-in-progress.

_ _ Forthcoming. "Australian Government Bonds' Nominal Yields: A Keynesian Perspective." Annals of Financial Economics.

Akram, T., and H. Li. 2016. "The Empirics of Long-Term U.S. Interest Rates." Levy Economics Institute Working Paper No. 863. Annandale-on-Hudson, NY: Levy Economics Institute of Bard College.

—. 2017. "What Keeps Long-Term U.S. Interest Rates So Low?" Economic Modelling 60: $380-90$.

_ 2018. "The Dynamics of JGBs' Nominal Yields.” Levy Economics Institute Working Paper No. 906. Annandale-on-Hudson, NY: Levy Economics Institute of Bard College.

- 2019a. "The Impact of the Bank of Japan's Monetary Policy on Japanese Government Bonds' Low Nominal Yields.” Levy Economics Institute Working Paper No. 938. Annandale-on-Hudson, NY: Levy Economics Institute of Bard College.

—. 2019b. "An Inquiry Concerning Long-Term U.S. Interest Rates Using Monthly Data." Applied Economics. DOI: 10.1080/00036846.2019.1693696 (Available online only, accessed April 8, 2020).

Akram, T., and S. Uddin. 2020. "An Empirical Analysis of Long-Term Brazilian Interest Rates." Unpublished work-in-progress. 
Ardagna, S., F. Caselli, and T. Lane. 2007. "Fiscal Discipline and the Cost of Public Debt Service: Some Estimates for OECD Countries." The B.E. Journal of Macroeconomics 7(1): $1-33$.

Bindseil, U. 2004. Monetary Policy Implementation: Theory, Past, and Present. Oxford and New York: Oxford University Press.

Black, F., E. Derman, and W. Toy. 1990. “A One-factor Model of Interest Rates and Its Application to Treasury Bond Options.” Financial Analysts Journal 46(1): 33-39.

Bölükbaş, M. 2018. "The Fiscal Theory of The Price Level: An Analysis for Fragile Countries." In İsmail Şiriner and Zişan Yardım Kiliçkan (eds.), Institutions, Development \& Economic Growth. London: IJOPEC Publications Limited.

Brace, A., D. Gatarek, and M. Museiela. 1997. "The Market Model of Interest Rate Dynamics." Mathematical Finance 7(2): 127-54.

Cox J., J. Ingersoll, and S. Ross. 1985. "A Theory of the Term Structure of Interest Rates.” Econometrica 53(2): 385-467.

Das, U. S., M. Papaioannou, G. Pedras, F. Ahmed, and J. Surti. 2010. "Managing Public Debt and Its Financial Stability Implications.” IMF Working Paper 10/280. Washington, DC: International Monetary Fund.

Dothan, L. U. 1978. "On the Term Structure of Interest Rates.” Journal of Financial Economics 6(1): 59-65.

Fullwiler, S. T. 2016. “The Debt Ratio and Sustainable Macroeconomic Policy.” World Economic Review 7: 12-42.

—. (2008) 2017. "Modern Central Bank Operations: The General Principles.” In LouisPhilippe Rochon and Sergio Rossi, (eds.), Advances in Endogenous Money Analysis. Northampton, MA: Edward Elgar.

Goodheart, C. A. E. 1998. "Two Concepts of Money: Implications for the Analysis of Optimal Currency Areas." European Journal of Political Economy 14(3): 407-32.

Gruber, J. W., and S. B. Kamin. 2012. "Fiscal Positions and Government Bond Yields in OECD Countries." Journal of Money, Credit, and Banking 44(8): 1563-87.

Heath, D., R. Jarrow, and A. Morton. 1992. "Bond Pricing and the Term Structure of the Interest Rates: A New Methodology." Econometrica 60(1): 77-105.

Heston, S. 1993. "A Close Form-Solution for Options with Stochastic Volatility with Application to Bond and Currency Options.” Review of Financial Studies 6(2): 327-43. 
Ho, T. S .Y., and S. Lee. 1986. "Term Structure Movements and Pricing Interest Contingent Claims.” Journal of Finance 41(5): 1011-29.

Horioka, C. Y., T. Nomoto, and A. Terada-Hagiwara. 2014. "Why Has Japan's Massive Government Debt Not Wreaked Havoc (Yet)?” The Japanese Political Economy 40(2): $3-23$.

Hoshi, T., and T. Ito. 2013. "Is the Sky the Limit? Can Japanese Government Bonds Continue to Defy Gravity?" Asian Economic Policy Review 8(2): 218-47.

Hull, J. C., and A. White. 1990a. "Pricing Interest Rate Derivative Securities." Review of Financial Studies 3(4): 573-92.

_. 1990b. "Valuing Derivative Securities Using the Finite Difference Method." Journal of Financial and Quantitative Analysis 25(1): 87-100.

Jaramillo, L., and A. Weber. 2013. "Bond Yields in Emerging Economies: It Matters What State You Are In.” Emerging Markets Review 17: 169-85.

Keynes, J. M. 1930a. A Treatise on Money, Vol. I: The Pure Theory of Money. London: Macmillan.

- 1930b. A Treatise on Money, Vol. II: The Applied Theory of Money. London: Macmillan.

— 2007 [1936]. The General Theory of Employment, Interest, and Money. New York: Palgrave Macmillan.

Kregel, J. 1980. "Markets and Institutions as Features of a Capitalistic Production System." Journal of Post Keynesian Economics 3(1): 32-48.

—. 2011. "Was Keynes' Monetary Policy À Outrance in the Treatise, A Forerunner of ZIRP and QE? Did He Change His Mind in the General Theory?" Levy Institute Policy Note No. 2011/4. Annandale-on-Hudson, NY: Levy Economics Institute of Bard College.

Kurihara, Y. 2015. “Asset Price and Monetary Policy: The Japanese Case.” Journal of Applied Finance and Banking 5(4): 1-9.

Lerner, A. P. 1943. "Functional Finance and the Federal Debt." Social Research 10(1): 38-51.

Levrero, E. S., and M. Deleidi. 2019. "The Causal Relationship Between Short-and Long-Term Interest Rates: An Empirical Assessment of the United States.” MPRA Paper No. 93608. Munich: Munich University Library.

Macrobond. Various years. Macrobond subscription services. https://www.macrobond.com (accessed January 8, 2020). 
Malliaropulos, D., and P. Migiakis. 2018. "Quantitative Easing and Sovereign Bond Yields: A Global Perspective.” Bank of Greece Working Paper, No. 253. Athens: Bank of Greece.

Mattos, O. B., F. Da Roz, F. O. Ultremare, and G. S. Mello. 2019. "Unconventional Monetary Policy and Negative Interest Rates: A Post-Keynesian Perspective on the Liquidity Trap and Euthanasia of the Rentier." Review of Keynesian Economics 7(2): 185-200.

Min, H. G., D. H. Lee, C. Nam, M. C. Park, and S. H. Nam. 2003. "Determinants of EmergingMarket Bond Spreads: Cross-Country Evidence." Global Finance Journal 14(3): 271-86.

Patra M. D., S. Pattanaik, J. John, and H. K. Behera, 2016. "Monetary Policy Transmission in India: Do Global Spillovers Matter?” RBI Occasional Papers, 37 (1\&2). Mumbai: Reserve Bank of India.

Poghosyan, T. 2014. "Long-Run and Short-Run Determinants of Sovereign Bond Yields in Advanced Economies." Economic Systems 38(1): 100-14.

Reinhart, C. M., and K. S. Rogoff. 2009. This Time is Different: Eight Centuries of Financial Folly. Princeton, NJ: Princeton University Press.

Rebonato R. 1996. Interest-Rate Options Models: Understanding, Analysing and Using Models for Exotic Interest-rate Options. Chichester, UK, and New York: John Wiley and Sons.

- 2004. Volatility and Correlation: The Perfect Hedger and the Fox. Chichester, UK: John Wiley and Sons.

Riefler, W. W. 1930. Money Rates and Money Markets in the United States. New York and London: Harper \& Brothers.

Sau, L. 2018. "Coping with Deflation and the Liquidity Trap in the Eurozone: A Post Keynesian Approach.” Journal of Post Keynesian Economics 41(2): 210-35.

Simoski, S. 2019. "A Keynesian Exploration of the Determinants of Government Bond Yields for Brazil, Colombia, and Mexico." Master of Science thesis, Levy Economics Institute of Bard College. Annandale-on-Hudson, NY: Levy Economics Institute of Bard College. https://digitalcommons.bard.edu/levy_ms/16 (accessed January 8, 2020)

Sims, C.A. 2013. "Paper Money." American Economic Review 103(2): 563-84.

Tkačevs, O., and K. Vilerts. 2019. "The Impact of Government Borrowing Costs on Fiscal Discipline." Kyklos 729(3): 446-71.

Turner, P. 2002. "Bond Markets in Emerging Economies: An Overview of Policy Issues.” BIS Papers No. 11. Basel: Bank for International Settlements. 
Vasicek, O. A. 1977. "An Equilibrium Characterization of the Term Structure." Journal of Financial Economics 5(2): 177-88.

Vinod, H. D., L. Chakraborty, and H. Karun. 2014. "If Deficits Are Not the Culprit, What Determines Indian Interest Rates? An Evaluation Using the Maximum Entropy Bootstrap Method.” Levy Economics Institute Working Paper No. 811. Annandale-on-Hudson, NY: Levy Economics Institute of Bard College.

Wray, L. R. (1998) 2003. Understanding Modern Money: The Key to Full Employment and Price Stability. Paperback edition. Cheltenham, UK, and Northampton, MA: Edward Elgar.

- 2012. Modern Money Theory: A Primer on Macroeconomics for Sovereign Monetary Systems. New York: Palgrave Macmillan. 